\title{
Antimicrobial activity of essential oils against Pasteurella spp. isolated from the oral cavity of domestic cats
}

\author{
Valéria Maria Lara Carregaro ${ }^{1 *}$ (i) Natália Bertini Contieri ${ }^{1}$ Camila Aparecida Cruz dos Reis ${ }^{1}$ \\ Mariel Dalmédico Policano ${ }^{1}$ Silvana Marina Piccoli Pugine ${ }^{2}$ Mariza Pires de Melo ${ }^{2}$ \\ Ana Maria Centola Vidal ${ }^{1}$ (D) Andréia Cristina Nakashima Vaz ${ }^{1}$ \\ Adriano Bonfim Carregaro ${ }^{1}$ Carlos Eduardo Ambrósio ${ }^{1}$ (D)
}

'Departamento de Medicina Veterinária, Universidade de São Paulo (USP), Faculdade de Zootecnia e Engenharia de Alimentos (FZEA), 13635-900, Pirassununga, SP, Brasil. E-mail: vallaracarregaro@gmail.com. *Corresponding author.

${ }^{2}$ Departamento de Ciências Básicas, Universidade de São Paulo (USP), Faculdade de Zootecnia e Engenharia de Alimentos (FZEA), Pirassununga, SP, Brasil.

ABSTRACT: Pasteurella spp. have been identified predominantly in the oral microbiota of domestic cats. However, Pasteurella spp. was significantly more prevalent in cats with inflammatory oral disease; and consequently, it was considered as part of the etiology in this disease. In addition, in animals, Pasteurella spp. have become increasingly resistant to a large number of antimicrobials. Natural products, especially essential oils, could contribute to minimizing this issue. This study determined the minimum inhibitory concentration (MIC) and minimum bactericidal concentration $(M B C)$ of six essential oils against Pasteurella spp. isolates from the oral cavity of domestic cats. Our results showed that essential oils with better antimicrobial effectiveness against most of the Pasteurella isolates were lemongrass, tea tree and clove,

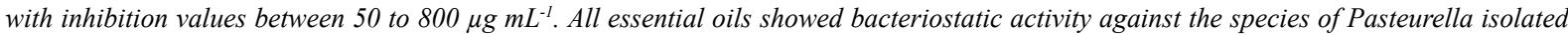
from the domestic cats. These results suggested that lemongrass, tea tree and clove oils have potential to be used in products for oral hygiene and treatment of oral infections in domestic cats.

Key words: cats, oral hygiene, essential oils, antimicrobial agents, Pasteurella.

Avaliação da atividade antimicrobiana de óleos essenciais frente a isolados de Pasteurella spp. oriundos da cavidade bucal de gatos domésticos

RESUMO: O gênero Pasteurella spp., considerado um comensal da cavidade bucal de gatos domésticos, vem sendo, nos últimos anos, apontado como possivel agente etiológico de quadros inflamatórios crônicos bucais em felinos. Ademais, em animais, as espécies de Pasteurella têm apresentado cada vez mais resistência a um grande número de antimicrobianos de uso rotineiro. Nesse contexto, os produtos naturais, como óleos essenciais com potencial antimicrobiano tem sido alvo de estudos e apontados como alternativa terapêtica. Neste estudo, objetivouse determinar a Concentração Minima Inibitória (CMI) e da Concentração Bactericida Mínima (CBM) de seis óleos essenciais frente a isolados de Pasteurella spp. oriundos da cavidade bucal de gatos domésticos. Dos óleos essenciais testados, o capim-limão, tea tree, cravo e a camomila romana apresentaram ação bacteriostática frente aos isolados de Pasteurella spp. Contudo, os óleos de capim-limão, tea-tree

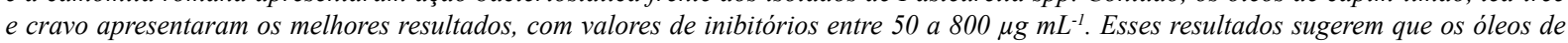
capim-limão, tea tree e cravo têm potencial para serem utilizados como produtos para higiene bucal e para o tratamento de infecções da cavidade bucal de gatos domésticos.

Palavras-chave: gatos, higiene bucal, óleos essenciais, agentes antimicrobianos, Pasteurella.

\section{INTRODUCTION}

The oral cavity of domestic cats has a microbiota rich in aerobic and anaerobic bacteria (KIL \& SWANSON, 2011). Some differences have been detected between bacterial microbiota from healthy or diseased oral cavities (DOLIESLAGER et al., 2011; DOLIESLAGER et al., 2013; STURGEON et al., 2014). Pasteurella spp. have been identified predominantly in the oral microbiota of healthy domestic animals (ABRAHAMIAN \& GOLDSTEIN, 2011). However, Pasteurella spp. was significantly more prevalent in cats with gingivitis than in healthy cats; and consequently, it was considered as part of the etiology in this disease (DOLIESLAGER et al., 2011). In addition, the genus Pasteurella has been the most prevalent genus in samples of human lesions caused by cat bites, resulting in cellulitis,

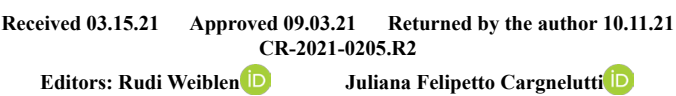


lymphangitis, abscesses, and septic arthritis (HEY et al., 2012; GUSTAVSON et al., 2016).

Penicillin and tetracyclines have been chosen as the best drug for the treatment of Pasteurella infections (LION et al., 2006; FERREIRA et al., 2015a), but there are some $\beta$-lactams antibiotics that have no antimicrobial effect, especially if used alone against different species of Pasteurella (WILSON \& HO, 2013). In human, antibiotic resistance has rarely been reported among Pasteurella spp. isolates. However, in animals, Pasteurella spp. have become increasingly resistant to a large number of antimicrobials (KEHRENBERG et al., 2001). In this sense, a study showed that $12.1 \%$ of Pasteurella multocida isolated from oral samples of domestic cats presented resistance to all tested antimicrobials, and $75.6 \%$ displayed resistance to sulfamethoxazole-trimethoprim and $60.9 \%$ to sulfisoxazole (FERREIRA et al., 2015b).

At present, multidrug resistant bacterial isolates have been frequently identified in small animals (GANDOLFI-DECRISTOPHORIS et al., 2013; LEITE-MARTINS et al., 2015; YUKAWA et al., 2017; PULSS et al., 2018). These findings are important as the population of domestic cats and the contact between these animals and humans has increased, allowing cross-transmission of these bacteria (LLOYD, 2007). Conversely, in the last years, the synthesis of new antimicrobials has diminished (RANA et al., 2019). Thus, new treatment options are necessary to overcome the advent of bacterial resistance and natural products have this potential, including plant essential oils (EOs), which are natural, volatile and complex products, originating from their secondary metabolism (LARA et al., 2016). These compounds present great therapeutic and pharmacological potential, especially antimicrobial activity (CHINSEMBU et al., 2016). This study evaluated the antimicrobial activity of six essential oils against fourteen isolates of Pasteurella spp. from the oral cavity of domestic cats.

\section{MATERIALS AND METHODS}

\section{Pasteurella spp. isolates}

The study was carried out with fourteen isolates of Pasteurella spp. from the Laboratory of Innovative Therapies, Department of Veterinary Medicine, Faculty of Animal Science and Food Engineering (FZEA), University of São Paulo (USP), Pirassununga, Brazil.

Pasteurella spp. were isolated by rubbing a sterile cotton-tipped swab over the teeth, gums, and tongue and then placing the swab into a glass bottle containing $1 \mathrm{~mL}$ of phosphate buffered saline. The bottle was mixed thoroughly using a vortex mixer and the resulting bacterial suspension was inoculated onto ovine blood agar (5\%) (Blood agar base, HiMedia Laboratories, Mubai, India) and chocolate agar (Blood agar base, HiMedia Laboratories, Mumbai, India). The media were incubated aerobically at $35{ }^{\circ} \mathrm{C}\left(+/-2{ }^{\circ} \mathrm{C}\right)$ for $24-48 \mathrm{~h}$ and pure cultures obtained. The isolates were identified using standard microbiological methods (ZBINDEN, 2015).

\section{Essential Oils (EOs)}

The EOs tested were bergamot (Citrus bergamia), roman chamomile (Anthemis nobile), lemongrass (Cymbopogon citratus), copaiba (Copaifera officinalis), clove (Eugenia caryophyllus) and tea tree (Melaleuca alternifolia). All oils were obtained commercially (Arte dos Aromas Indústria e Comércio Ltda, Brazil), and included a technical report of the chemical composition determined by gas chromatography (Table 1). All EOs were obtained in sealed amber glass bottles.

\section{Agar well diffusion test}

The agar well diffusion test was performed according to a previously described methodology (DUARTE et al., 2005), with minor modifications. Briefly, the inoculum of Pasteurella species was prepared in Mueller Hinton Broth (MHB, HiMedia Laboratories, India) at $37{ }^{\circ} \mathrm{C}$ for $24 \mathrm{~h}$. Pasteurella cultures in the exponential phase of growth were diluted with MHB and adjusted to McFarland scale 0.5 to obtain a final concentration of 1 to $2 \times 10^{8} \mathrm{CFU} / \mathrm{mL}$ for use in the assays. Then, the inoculum was added to Mueller Hinton agar (MHA, HiMedia Laboratories, India) at $50{ }^{\circ} \mathrm{C}$ and distributed in $150 \mathrm{~mm}$ Petri plates. After the agar solidified nine holes were bored in each plate with a sterile tip $(1 \mathrm{~mL})$, and in each of them 40 $\mu \mathrm{L}\left(1600 \mu \mathrm{g} \mathrm{mL}^{-1}\right)$ of the EO to be tested was added. All the EOs were diluted in $80 \%$ (v/v) ethanol (Sigma, EUA). The $80 \%$ ethanol was used as a negative control and gentamicin (25 mg mL $\mathrm{mL}^{-1}$, Sigma, EUA) as an internal control in all plates. The plates were then incubated in a bacteriological incubator at 37 ${ }^{\circ} \mathrm{C}$ for $24 \mathrm{~h}$. Antibacterial activity was determined by measuring the diameter of the zone of inhibition (mm) surrounding bacterial growth. The zone of inhibition above $7 \mathrm{~mm}$ in diameter was taken as positive result. The tests were performed in duplicate.

Determination of minimum inhibitory concentration (MIC) The determination of the MIC of essential oils from roman chamomile, lemongrass, clove, 
Table 1 - Chemical composition of the roman chamomile, clove, tea tree, lemongrass, bergamot and copaiba oils.

\begin{tabular}{|c|c|c|c|c|c|c|}
\hline Compound & $\mathrm{RC}^{1}(\%)$ & $\mathrm{CL}^{2}(\%)$ & $\mathrm{TT}^{3}(\%)$ & $\mathrm{LG}^{4}(\%)$ & $\mathrm{BG}^{5}(5)$ & $\mathrm{CP}^{6}(\%)$ \\
\hline Geranial & - & - & - & $2.5-10$ & - & - \\
\hline Limonene & - & 0.01 & - & & 45 & - \\
\hline Citronellal & - & - & - & $\leq 2.5$ & - & - \\
\hline Linalool & - & 0.1 & - & $\leq 2.5$ & 15 & - \\
\hline terpinen-4-ol & - & - & $25-50$ & - & - & - \\
\hline$\alpha$-terpinene & - & - & $10-25$ & - & - & - \\
\hline isobutyl angelate & $25-40$ & - & - & - & & - \\
\hline$\alpha$-Pinene & & - & - & - & 2 & - \\
\hline$\beta$-Pinene & & - & - & - & 2 & - \\
\hline p-menta-1,3-dieno & - & - & $10-25$ & - & - & - \\
\hline 1,8 cineol & & - & $\leq 2.5$ & - & - & - \\
\hline Geranyl acetate & - & - & - & $2.5-10$ & - & - \\
\hline Citral & - & - & - & $50-100$ & - & - \\
\hline B-Myrcene & 0.1 & - & - & $10-15$ & - & - \\
\hline Linalyl acetate & - & - & - & - & 35 & - \\
\hline Tocopherol & - & - & - & - & - & $<0.1$ \\
\hline trans- $\beta$-Caryophyllene & - & - & - & - & - & $>50$ \\
\hline Methil Eugenol & & 0.1 & & & & \\
\hline Isoeugenol & - & 0,5 & - & - & - & - \\
\hline Eugenol & - & 92 & - & - & - & - \\
\hline
\end{tabular}

${ }^{1} \mathrm{RC}$, Roman chamomile oil; ${ }^{2} \mathrm{Cl}$, Clove oil; ${ }^{3} \mathrm{TT}$, Tea tree oil; ${ }^{4} \mathrm{LG}$, Lemongrass oil; ${ }^{5} \mathrm{BG}$, Bergamot oil; ${ }^{6} \mathrm{CP}$, Copaiba oil. Results expressed as $\%$.

and tea tree was performed according to the broth macrodilution method previously described (DUARTE et al., 2005), with some modifications. Briefly, from the stock culture of Pasteurella isolates, the inoculum was prepared in MHB (HiMedia Laboratories, India) and incubated under shaking at $37{ }^{\circ} \mathrm{C}$ for 24 h. The inoculum was diluted with MHB (HiMedia Laboratories, India) and adjusted to $0.5 \mathrm{McF}$ arland to obtain a final concentration of 1 to $2 \times 10^{8} \mathrm{CFU} / \mathrm{mL}$. Subsequently, $1.95 \mathrm{~mL}$ of the bacterial inoculum plus $0.05 \mathrm{~mL}$ of the diluted essential oils were added into glass tubes, at the following concentrations: $1600 \mu \mathrm{g}$ $\mathrm{mL}^{-1}, 800 \mu \mathrm{g} \mathrm{mL}^{-1}, 400 \mu \mathrm{g} \mathrm{mL}^{-1}, 200 \mu \mathrm{g} \mathrm{mL}^{-1}, 100 \mu \mathrm{g}$ $\mathrm{mL}^{-1}, 50 \mu \mathrm{g} \mathrm{mL}^{-1}, 25 \mu \mathrm{g} \mathrm{mL} \mathrm{L}^{-1}$ and $12.5 \mu \mathrm{g} \mathrm{mL}^{-1}$. All tubes were incubated under shaking at $100 \mathrm{rpm}$ for 18 to $24 \mathrm{~h}$ at $37^{\circ} \mathrm{C}$. Four internal controls were used for the test: 1) Mueller Hinton broth (MHB, HiMedia Laboratories, India) alone; 2) Pure bacterial inoculum; 3) Gentamicin (25 mg mL-1 , Sigma, EUA); and 4) $80 \%$ ethanol (Sigma, EUA) (Figure 1). The analyses were performed in duplicate.

At the end of the incubation period, 0.3 $\mathrm{mL}$ of each tube was transferred to 96-well microtiter plates and the absorbance $(620 \mathrm{~nm})$ was recorded. In addition, after the spectrophotometric reading, 0.005 $\mathrm{mL}$ resazurin $\left(3 \mathrm{mg} \mathrm{mL} \mathrm{m}^{-1}\right.$, Rezazurin sodium salt, Sigma, EUA) was added in each well. Then, the plates were placed under shaking at $37^{\circ} \mathrm{C}$ for $30 \mathrm{~min}$ at 60 min (or until color change) and a new reading was carried out. The interpretation of the results was based on the coloring, with blue color interpreted as absence of bacterial proliferation and pink as the presence of bacterial proliferation (SARKER et al., 2007).

\section{Determination of Minimum Bactericidal Concentration (MBC)}

$\mathrm{MBC}$ is the lowest concentration of essential oils required to kill the inoculum, and it was determined in the wells with no visible bacterial growth in the MIC assay after $24 \mathrm{~h}$ of incubation (LARA et al., 2016). A 0.1 $\mathrm{mL}$ aliquot was transferred from these wells to the surface of Muller Hinton agar (MHA, HiMedia Laboratories, India) and incubated at $37{ }^{\circ} \mathrm{C}$ for $24 \mathrm{~h}$. Subsequently, a visual inspection of the plates was performed. The interpretation of results was based on the presence of colonies (RADAELLI et al., 2016); the presence of them 


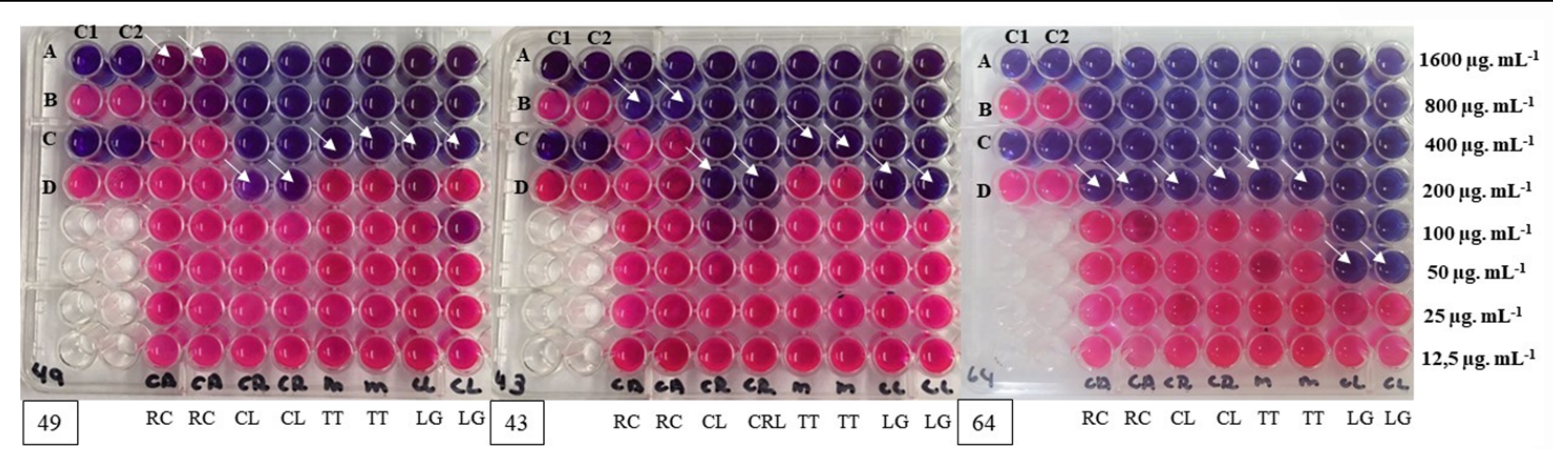

Figure 1 - Minimal inhibitory concentration (MIC, $\mu \mathrm{g} \mathrm{mL}^{-1}$ ) against isolates of Pasteurella spp. from samples of the oral cavity of domestic cats.

The white arrows indicate the MICs values. Disclosure by resazurin, blue color indicates inhibition of bacterial proliferation and pink color indicates bacterial proliferation. $\mathrm{C} 1$ and $\mathrm{C} 2=$ controls, $\mathrm{A}=$ Mueller Hinton broth $(\mathrm{MHB}$, HiMedia Laboratories, India) alone; $\mathrm{B}=$ Pure bacterial inoculum; $\mathrm{C}=$ Gentamicin $(25 \mathrm{mg} \mathrm{mL}-1) ; \mathrm{D}=80 \%$ Ethanol; $\mathrm{RC}=$ Roman chamomile oil; $\mathrm{CL}=\mathrm{Clove}$ oil; $\mathrm{TT}=\mathrm{Tea}$ tree oil; $\mathrm{LG}=$ Lemongrass oil.

indicated that $\mathrm{EO}$ had bacteriostatic activity, whereas the absence of them indicated bactericidal activity of the EO tested. The assay was performed in duplicate.

\section{RESULTS AND DISCUSSION}

We tested the inhibitory and bactericidal effects of six essential oils on fourteen Pasteurella spp. isolates. Our results revealed the best bacteriostatic activity was achieved by lemongrass oil, with average of inhibition halo between 20 to $23 \mathrm{~mm}$ and with MICs and MBCs values ranging from 50 to $400 \mu \mathrm{g} \mathrm{mL}^{-1}$ (Figure 1, Tables 2 and 3). Lemongrass oil has been used for several purposes, as a natural antibiotic for quite some time (NAIK et al., 2010; BASSOLÉ et al., 2011; KORENBLUM et al., 2013; OLIVEIRA et al., 2013).

Table 2 - Diameter of inhibition zone expressed in $\mathrm{mm}$ of six investigated essential oils against isolates of Pasteurella spp. from samples of the oral cavity of domestic cats.

\begin{tabular}{|c|c|c|c|c|c|c|c|c|}
\hline Pasteurella spp. strains & $\mathrm{RC}^{1}$ & $\mathrm{CL}^{2}$ & $\mathrm{TT}^{3}$ & $\mathrm{LG}^{4}$ & $\mathrm{BG}^{5}$ & $\mathrm{CP}^{6}$ & Gent $^{7}$ & $\mathrm{ET}^{8}$ \\
\hline 1 & 11 & 14 & 11 & 21 & 0 & 3 & 25 & 0 \\
\hline 2 & 11 & 14 & 12 & 20 & 0 & 0 & 28 & 0 \\
\hline 3 & 12 & 15 & 11 & 22 & 2 & 4 & 29 & 0 \\
\hline 4 & 13 & 16 & 14 & 23 & 3 & 3 & 26 & 0 \\
\hline 5 & 13 & 16 & 14 & 20 & 0 & 0 & 25 & 0 \\
\hline 6 & 13 & 14 & 13 & 20 & 0 & 0 & 26 & 0 \\
\hline 7 & 11 & 15 & 13 & 23 & 2 & 3 & 28 & 0 \\
\hline 8 & 12 & 15 & 12 & 21 & 2 & 0 & 27 & 0 \\
\hline 9 & 13 & 15 & 14 & 22 & 0 & 0 & 29 & 0 \\
\hline 10 & 13 & 14 & 14 & 23 & 0 & 0 & 25 & 0 \\
\hline 11 & 11 & 14 & 11 & 21 & 0 & 0 & 28 & 0 \\
\hline 12 & 12 & 15 & 12 & 22 & 0 & 0 & 27 & 0 \\
\hline 13 & 12 & 16 & 13 & 21 & 0 & 0 & 26 & 0 \\
\hline 14 & 13 & 16 & 14 & 20 & 0 & 0 & 28 & 0 \\
\hline
\end{tabular}

${ }^{1} \mathrm{RC}$, Roman chamomile oil; ${ }^{2} \mathrm{Cl}$, Clove oil; ${ }^{3} \mathrm{TT}$, Tea tree oil; ${ }^{4} \mathrm{LG}$, Lemongrass oil; ${ }^{5} \mathrm{BG}$, Bergamot oil; ${ }^{6} \mathrm{CP}$, Copaiba oil; ${ }^{7} \mathrm{Gent}$, Gentamicin; ${ }^{8} \mathrm{ET}, 80 \%$ Ethanol Results expressed as mm. 
Table 3 - MIC and MBC of four essential oils against isolates of Pasteurella spp. from samples of the oral cavity of domestic cats.

\begin{tabular}{|c|c|c|c|c|c|c|c|c|}
\hline \multirow{3}{*}{ Pasteurella spp. strains } & \multicolumn{2}{|c|}{-------------RC } & \multicolumn{2}{|c|}{-------------CL ${ }^{2}$------------ } & \multicolumn{2}{|c|}{ 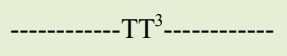 } & \multicolumn{2}{|c|}{------------LG ${ }^{4}-----------$} \\
\hline & $\mathrm{MIC}^{\mathrm{a}}$ & $\mathrm{MBC}^{\mathrm{b}}$ & MIC & MBC & MIC & $\mathrm{MBC}$ & MIC & $\mathrm{MBC}$ \\
\hline & \multicolumn{2}{|c|}{-------( $\left(\mu \mathrm{g} \mathrm{mL}^{-1}\right)-------$} & \multicolumn{2}{|c|}{ 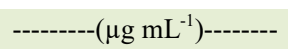 } & \multicolumn{2}{|c|}{-------- $\left.\mu \mathrm{g} \mathrm{mL} \mathrm{mL}^{-1}\right)-------$} & \multicolumn{2}{|c|}{------( $\left(\mu \mathrm{g} \mathrm{mL}^{-1}\right)------$} \\
\hline 1 & 100 & 100 & 200 & 200 & 200 & 200 & 50 & 50 \\
\hline 2 & 100 & 100 & 200 & 400 & 200 & 400 & 50 & 100 \\
\hline 3 & 200 & 200 & 400 & 400 & 200 & 400 & 50 & 50 \\
\hline 4 & 200 & 800 & 400 & 400 & 400 & 400 & 100 & 100 \\
\hline 5 & ND & ND & 800 & 800 & 400 & 400 & 200 & 400 \\
\hline 6 & 1600 & ND & 400 & 400 & 400 & 400 & 50 & 50 \\
\hline 7 & 800 & 1600 & 800 & 800 & 200 & 400 & 100 & 100 \\
\hline 8 & 800 & 800 & 200 & 400 & 200 & 400 & 100 & 200 \\
\hline 9 & 200 & 800 & 400 & 800 & 200 & 200 & 100 & 200 \\
\hline 10 & 100 & 100 & 200 & 200 & 400 & 400 & 50 & 200 \\
\hline 11 & 100 & 400 & 800 & 400 & 200 & 200 & 100 & 200 \\
\hline 12 & 400 & ND & 200 & 200 & 200 & 400 & 100 & 100 \\
\hline 13 & 400 & 800 & 200 & 400 & 200 & 400 & 200 & 200 \\
\hline 14 & ND & ND & 800 & 800 & 400 & 400 & 400 & 400 \\
\hline
\end{tabular}

${ }^{1} \mathrm{RC}$, Roman chamomile oil; ${ }^{2} \mathrm{CL}$, Clove oil; ${ }^{3} \mathrm{TT}$, Tea tree oil; ${ }^{4} \mathrm{LG}$, Lemongrass oil.

${ }^{\mathrm{a}} \mathrm{MIC}$, Minimum inhibitory concentration; ${ }^{\mathrm{b}} \mathrm{MBC}$, Minimum Bactericidal Concentration.

ND, Not determined.

Several chemical compounds, such as citral, $\beta$-myrcene, dipentene, linalool, geranial, citronellol, among others have already been identified in the lemongrass oil composition (BASSOLÉ et al., 2011). Nevertheless, its antimicrobial activity has been attributed to the major presence of citral (PRABUSEENIVASAN et al., 2006; BASSOLÉ et al., 2011). In agreement, our results reinforce this fact, as the chemical compound with the highest concentration in the lemongrass tested was citral (50 to $100 \%$, manufacturer's report). In the study of MAYAUD et al. (2008), the authors demonstrated that lemongrass displayed antibacterial activity against $P$. multocida. The chemical composition of the lemongrass oil tested by these authors had high concentrations of citral, which strengthens the theory cited above.

The tea tree oil also had antimicrobial efficacy against isolates of Pasteurella spp. with average of inhibition halo between 11 to $14 \mathrm{~mm}$ and MICs and MBCs values ranging from 200 to $400 \mu \mathrm{g}$ $\mathrm{mL}^{-1}$ (Tables 2 and 3 ). The antimicrobial activity of tea tree oil has been attributed to the terpinen-4-ol, which is reported as the major compound, comprising approximately $40 \%$ of the composition of the EO (OLIVEIRA et al., 2013). The tea tree oil used in the present study also presented a high concentration of terpinen-4-ol (25 to 50\%, manufacturer's report) in its composition, highlighting that perhaps this chemical compound is the main agent with antimicrobial activity. It is important to note that the tea tree oil has been used commercially in oral antiseptics.

The average of inhibition zone from the clove oil was between 14 to $16 \mathrm{~mm}$ against all the isolates Pasteurella. spp. MAYAUD et al. (2008) tested the sensitivity of $P$. multocida isolated from humans with clove and obtained a MIC value of $0.47 \%$ (v/v). In our study the MICs and MBCs values was $0.09 \%(\mathrm{v} / \mathrm{v})\left(200\right.$ to $\left.800 \mu \mathrm{g} \mathrm{mL}^{-1}\right)$. The discrepancies between results may be attributed the techniques used, as well as the form of dilution and incorporation of EO to the culture medium. In addition, differences between the concentrations of eugenol, the main chemical compound with antimicrobial activity, may explain the discrepancies between our results and another study (MAYAUD et al., 2008), which were $92 \%$ and $75.52 \%$, respectively.

The least active oil was roman chamomile, with generally lower bacteriostatic activity (MICs and MBCs $=100$ to $\left.1600 \mu \mathrm{g} \mathrm{mL}^{-1}\right)$, since some isolates of Pasteurella spp. were resistant. In the agar diffusion test, the Pasteurella spp. isolates showed inhibition zone between 11 to $13 \mathrm{~mm}$ in the presence of roman chamomile oil. In previous study, the antimicrobial activity of roman chamomile oil against Gram- 
negative bacteria was mainly due to the presence of isobutyl and methylbutyl angelate and isobutyl isobutyrate, with an inhibition halo between 9 to 19 $\mathrm{mm}$ and with MICs values ranging from 60 to $600 \mu \mathrm{g}$ $\mathrm{mL}^{-1}$ (BAIL et al., 2009). One important observation which may explain the differences in results is that only isobutyl angelate was present in the composition of the roman chamomile oil tested by us.

Furthermore, the copaiba and bergamot oils failed to inhibit any of the tested isolates. The absence of antimicrobial activity of copaiba against the isolates of Pasteurella, a Gram-negative bacterium, was similar to another study, which had demonstrated that this oil possibly does not possess activity against Gram-negative bacteria (SANTOS et al., 2008). It could be explained by the intrinsic tolerance of some Gram-negative bacteria to plant volatile compounds, mainly due to the composition of their cell wall (COX \& MARKHAM, 2007).

In addition, the absence of antimicrobial activity of bergamot was in contrast with other studies (FISHER \& PHILLIPS, 2006; MANDALARI et al., 2007), which reported antimicrobial activity compared to different genera of Gram-negative bacteria. It should be noted that, to date, there are no published studies that have studied the sensitivity of Pasteurella spp. to three EOs (bergamot, copaiba, and roman chamomile). At the same time, this difference in our results may be due to the chemical composition of the oils tested. Apart from the different concentrations of the compounds and the synergism among them, other possible explanations for discrepant results between scientific studies are the phytogeographic origin, the season of the year and the mode of cultivation of the plant used to obtain the extract of the EOs. It has already been shown these factors affect the composition of the EO (BURT, 2004) and consequently their activity.

In conclusion, only the EOs of lemongrass, clove and tea tree displayed acceptable antimicrobial activity against Pasteurella spp. isolates from the oral cavity of domestic cats. Nevertheless, the results suggested that these three EOs have potential to be used in products for oral hygiene and maybe treatment of oral infections caused by Pasteurella spp. in domestic cats. However, further studies are necessary to demonstrate this potential, especially with respect to toxicity tests in vitro and in vivo.

\section{ACKNOWLEDGEMENTS}

This study was financed in the part by the Coordenação de Aperfeiçoamento de Pessoal de Nível SuperiorBrasil (CAPES)-Finance Code 001.

\section{BIOETHICS AND COMMITTEE APROVAL}

BIOSSECURITY

The Bioethical Committee of the FZEA Universidade de São Paulo, Pirassununga, SP, Brazil has approved this study under the protocol number 14.1.1500.74.6. All animals were handled according to the National Institutes of Health Guide for the Care and Use of the Laboratory Animals.

\section{DECLARATION OF CONFLICT OF INTEREST}

We have no conflict of interest to declare with respect to the research, authorship and/or publication of this article.

\section{AUTHOR'S CONTRIBUTIONS}

All authors contributed equally for the conception and writing of the manuscript. All authors critically revised the manuscript and approved of the final version.

\section{REFERENCES}

ABRAHAMIAN, F. M.; GOLDSTEIN, E. J. C. Microbiology of animal bite wound infections. Clinical Microbiology Reviews, v.24, n.2, p.231-246, 2011. Available from: <https: // doi.org/10.1128/CMR.00041-10>. Accessed: Mar. 08, 2021. doi: 10.1128/CMR.00041-10.

BAIL, S. et al. Antimicrobial activities of roman chamomile oil from France and its main compounds. Journal Essential Oil Research, v.21, p.283-86, 2009. Available from: <https://doi.org/ 10.1080/10412905.2009.9700171>. Accessed: Mar. 08, 2021. doi: 10.1080/10412905.2009.9700171.

BASSOLÉ, I. H. N. et al. Chemical composition and antimicrobial activity of Cymbopogon citratus and Cymbopogon giganteus essential oils alone and in combination. Phytomedicine, v.18, n.12, p.1070-1074, 2011. Available from: <https://doi.org/10.1016/j. phymed.2011.05.009>. Accessed: Mar. 08, 2021. doi: 10.1016/j. phymed.2011.05.009.

BURT, S. A. Essential oils: their antibacterial properties and potential applications in foods - a review. International Journal Food Microbiology, v.94, n.3, p.223-253, 2004. Available from: $<$ https://doi.org/10.1016/j.ijfoodmicro.2004.03.022>. Accessed: Mar. 08, 2021. doi: 10.1016/j.ijfoodmicro.2004.03.022.

CHINSEMBU, K. C. Plants and other natural products used in the management of oral infections and improvement of oral healthy. Acta Tropica, v.154, p.6-18, 2016. Available from: <https://doi. org/10.1016/j.actatropica.2015.10.019>. Accessed: Mar. 08, 2021. doi: 10.1016/j.actatropica.2015.10.019.

COX, S. D.; MARKHAM, J. L. Susceptibility and intrinsic tolerance of Pseudomonas aeruginosa to selected plant volatile compounds. Journal Applied Microbiology, v.103, n.4, p.930-936, 2007. Available from: <https://doi.org/10.111 1/j.1365-2672.2007.03353.x>. Accessed: Mar. 08, 2021. doi: 10.1111/j.1365-2672.2007.03353.x.

DOLIESLAGER, S. M. J. et al. Identification of bacteria associated with feline chronic gingivostomatitis using culture-dependent and 
culture-independent methods. Veterinary Microbiology, v.148, n.1, p.93-98, 2011. Available from: <https: //doi.org/10.1016/j. vetmic.2010.08.002 $>$. Accessed: Mar. 08, 2021. doi: 10.1016/j. vetmic.2010.08.002

DOLIESLAGER, S. M. J. et al. Novel bacterial phylotypes associated with the healthy feline oral cavity and feline chronic gingivostomatitis. Research Veterinary Science, v.94, n.3, p.428-432, 2013. Available from: <https: //doi.org/10.1016/j. rvsc.2012.11.003>. Accessed: Mar. 08, 2021. doi: 10.1016/j. rvsc.2012.11.003.

DUARTE, M. C. T. et al. Anti-candida activity of Brazilian medicinal plants. Journal Ethnopharmacology, v.97, n.2, p.305-311, 2005. Available from: <https://doi.org/10.1016/j. jep.2004.11.016>. Accessed: Mar. 08, 2021. doi: 10.1016/j. jep.2004.11.016

FERREIRA, J. et al. Pneumonia and disseminated bacteremia with Pasteurella multocida in the immune competent host: A case report and a review of the literature. Respiratory Medicine Case Reports, v.15, p.54-56, 2015a. Available from: $<$ https://doi. org/10.1016/j.rmcr.2015.04.005>. Accessed: Mar. 08, 2021. doi: 10.1016/j.rmcr.2015.04.005.

FERREIRA, T. S. P. et al. Antimicrobial resistance and virulence gene profiles in P. multocida strains isolated from cats. Brazilian Journal Microbiology, v.46, n.1, p.271-277, 2015b. Available from: $\quad$ http://dx.doi.org/10.1590/S1517-838246120140084>. Accessed: Mar. 08, 2021. doi: 10.1590/S1517-838246120140084.

FISHER, K.; PHILLIPS, C. A. The effect of lemon, orange and bergamot essential oils and their components on the survival of Campylobacter jejuni, Escherichia coli 0157, Listeria monocytogenes, Bacillus cereus and Staphylococcus aureus in vitro and in food systems. Journal Applied Microbiology, v.101, n.6, p.1232-1240, 2006. Available from: <http://dx.doi.org/10.1 111/j.1365-2672.2006.03035.x> Accessed: Mar. 08, 2021. doi: $10.1111 / j .1365-2672.2006 .03035 . x$

GANDOLFI-DECRISTOPHORIS, P. et al. Prevalence and risk factors for carriage of multi-drug resistant Staphylococci in healthy cats and dogs. Journal Veterinary Science, v.14, n.4, p.449-456, 2013. Available from: <https://doi.org/10.4142/ jvs.2013.14.4.449>. Accessed: Mar. 08, 2021. doi: $10.4142 /$ jvs.2013.14.4.449.

GUSTAVSON, O. et al. A wide spectrum of fastidious and ampicillin-susceptible bacteria dominate in animal-caused wounds. European Journal Clinical Microbiology Infectious Diseases, v.35, n.8, p.1315-1321, 2016. Available from: <https:// doi.org/10.1007/s10096-016-2667-z>. Accessed: Mar. 08, 2021. doi: 10.1007/s10096-016-2667-z.

HEY, P. et al. Cirrhosis, cellulitis and cats: a 'purrfect' combination for life-threatening spontaneous bacterial peritonitis from Pasteurella multocida. BMJ Case Reports, v.11, p.1-3, 2012. Available from: <http://dx.doi.org/10.1136/bcr-2012-007397>. Accessed: Mar. 08, 2021. doi: 10.1136/bcr-2012-007397.

KEHRENBERG, C. et al. Antimicrobial resistance in Pasteurella and Mannheimia: epidemiology and genetic basis. Veterinary Research, v.32, n.3-4, p.323-339, 2001. Available from: <https:// doi.org/10.1051/vetres:2001128>. Accessed: Mar. 08, 2021. doi: 10.1051/vetres: 2001128
KIL, D. Y.; SWANSON, K. S. Companion animals symposium: role of microbes in canine and feline health. Journal Animal Science, v.89, n.5, p.1498-1505, 2011. Available from: <https:// doi.org/10.2527/jas.2010-3498>. Accessed: Mar. 08, 2021. doi: $10.2527 /$ jas.2010-3498.

KORENBLUM, E. et al. Antimicrobial action and anticorrosion effect against sulfate reducing bacteria by lemongrass (Cymbopogon citratus) essential oil and its major component, the citral. AMB express, v.3, n.44, 2013. Available from: <https:// doi.org/10.1186/2191-0855-3-44>. Accessed: Mar. 08, 2021. doi: $10.1186 / 2191-0855-3-44$

LARA, V. M. et al. Antimicrobial susceptibility of Escherichia coli strains isolated from Alouatta spp. feces to essential oils. Evidence Based Complementary Alternative Medicine, v.2016:1643762, 2016. Available from: <https://doi.org/10.1155/2016/1643762>. Accessed: Mar. 08, 2021. doi: 10.1155/2016/1643762.

LION, C. et al. Antimicrobial susceptibilities of Pasteurella strains isolated from humans. International Journal Antimicrobial Agents, v.27, n.4, p.290-293, 2006. Available from: $<$ https://doi. org/10.1016/j.ijantimicag.2006.02.004>. Accessed: Mar. 08, 2021. doi: 10.1016/j.ijantimicag.2006.02.004.

LEITE-MARTINS, L. et al. Prevalence of antimicrobial resistante in faecal Enterococci from vet-visiting pets and assessment of risk factors. Veterinary Record, v.176, n.26, p.674, 2015. Available from: <https://doi.org/10.1136/vr.102888>. Accessed: Mar. 08, 2021. doi: $10.1136 /$ vr.102888

LLOYD, D. H. Reservoirs of antimicrobial resistance in pet animals. Clinical Infectious Diseases, v.1, n.45, Suppl 2, p.S14852, 2007. Available from: <https://doi.org/10.1086/519254>. Accessed: Mar. 08, 2021. doi: 10.1086/519254.

MANDALARI, G. et al. Antimicrobial activity of flavonoides extracted from bergamot (Citrus bergamia Risso) peel, a byproduct of essential oil industry. Journal Applied Microbiology, v.103, n.6, p.2056-2064, 2007. Available from: <https://doi.org/10.11 11/j.1365-2672.2007.03456.x>. Accessed: Mar. 08, 2021. doi: 10.1111/j.1365-2672.2007.03456.x.

MAYAUD, L. et al. Comparison of bacteriostatic and bactericidal activity of 13 essential oils against strains with varying sensitivity to antibiotics. Letter Applied Microbiology, v.47, n. 3, p.167-173, 2008. Available from: <https://doi.org/10.1111/ j.1472-765X.2008.02406.x>. Accessed: Mar. 08, 2021. doi: 10.1111/j.1472-765X.2008.02406.x.

NAIK, M. I. et al. Antibacterial activity of lemongrass (Cymbopogon citratus) oil against some selected pathogenic bacterias. Asian Pacific Journal Tropical Medicine, v.3, n.7, p.535-538, 2010. Available from: <https://doi.org/10.1016/S19957645(10)60129-0>. Accessed: Mar. 08, 2021. doi: 10.1016/S19957645(10)60129-0

OLIVEIRA, T. L. C. et al. A Weibull model to describe antimicrobial kinetics of oregano and lemongrass essential oils against Salmonella enteritidis in ground beef during refrigerated storage. Meat Science, v.93, n.3, p.645-651, 2013. Available from: $<$ https://doi.org/10.1016/j.meatsci.2012.11.004>. Accessed: Mar. 08, 2021. doi: 10.1016/j.meatsci.2012.11.004.

PRABUSEENIVASAN, S. et al. In vitro antibacterial activity of some plant essential oils. BMC Complementary Alternative 
Medicine, v.6, n.39, 2006. Available from: <https://doi. org/10.1186/1472-6882-6-39>. Accessed: Mar. 08, 2021. doi: $10.1186 / 1472-6882-6-39$.

PULSS, S. et al. Multispecies and clonal dissemination of Oxa48 carbapenemase in Enterobacteriaceae from companion animals in Germany, 2009-2016. Frontiers Microbiology, v.14, n.9, p.1265, 2018. Available from: <https://doi.org/10.3389/ fmicb.2018.01265>. Accessed: Mar. 08, 2021. doi: 10.3389/ fmicb.2018.01265.

RADAELLI, M. et al. Antimicrobial activities of six essential oils commonly used as condiments in Brazil against Clostridium perfringens. Brazilian Journal Microbiology, v.47, n.2, 424-430, 2016. Available from: <http://dx.doi.org/10.1016/j. bjm.2015.10.001>. Accessed: Mar. 08, 2021. doi: 10.1016/j. bjm.2015.10.001.

RANA, R. et al. Repurposing of Existing Statin drugs for treatment of Microbial Infections: How much Promising? Infectious Disorders Drug Targets, v.19, n.3, p.224-237, 2019. Available from: <https:// doi.org/10.2174/1871526518666180806123230>. Accessed: Mar. 08, 2021. doi: $10.2174 / 1871526518666180806123230$.

SANTOS, A. O. et al. Antimicrobial activity of Brazilian copaiba oils obtained from different species of the Copaifera genus. Memórias Instituto Oswaldo Cruz, v.103, n.3, p.277281, 2008. Available from: <https://doi.org/10.1590/S007402762008005000015>. Accessed: Mar. 08, 2021. doi: 10.1590/ S0074-02762008005000015.
SARKER, S. D. et al. Microtitre plate-base antibacterial assay incorporating resazurin as an indicator of cell growth, and its application in the in vitro antibacterial screening of phytochemicals. Methods, v.42, n.4, p.321-324, 2007. Available from: $<$ https://doi. org/10.1016/j.ymeth.2007.01.006> . Accessed: Mar. 08, 2021. doi: 10.1016/j.ymeth.2007.01.006.

STURGEON, A. et al. Characterization of the oral microbiota of healthy cats using next-generation sequencing. Veterinary Journal, v.201, n.2, p.223-229, 2014. Available from: <https:// doi.org/10.1016/j.tvjl.2014.01.024>. Accessed: Mar. 08, 2021. doi: 10.1016/j.tvj1.2014.01.024.

WILSON, B. A.; HO, M. Pasteurella multocida: from zoonosis to cellular microbiology. Clinical Microbiology Reviews, v.26, n.3, p.631655, 2013. Available from: <https://doi.org/10.1128/CMR.00024-13>. Accessed: Mar. 08, 2021. doi: 10.1128/CMR.00024-13.

YUKAWA, S. et al. Antimicrobial resistance of Pseudomonas aeruginosa isolated from dogs and cats in primary veterinary Hospitals in Japan. Japanese Journal Infectious Diseases, v.70, n.4, p.461-463, 2017. Available from: <https://doi.org/10.7883/yoken.JJID.2016.536>. Accessed: Mar. 08, 2021. doi: 10.7883/yoken.JJID.2016.536.

ZBINDEN, R. Aggregatibacter, Capnocytophaga, Eikenella, Kingella, Pasteurella, and other fastidious or rarely encountered Gram-negative rods. In: Manual of Clinical Microbiology, $11^{\text {th }}$ Ed.; Jorgensen, J.H.; Pfaller, M.A.; Carroll, K.C.; Funke, G.; Landry, M.L.; Richter, S.S.; Warnock, D.W.; ASM Press: Washington, EUA, 2015; Volume 1, pp.652-666. 